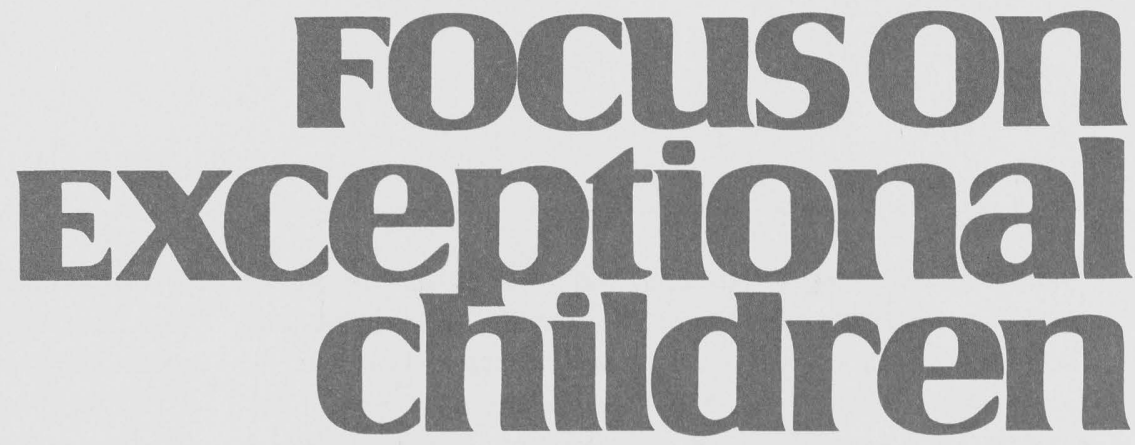

\title{
Effective Instruction for Culturally and Linguistically Diverse Students: A Reconceptualization
}

\author{
Russell Gersten, Susan Brengelman, and Robert Jiménez
}

Special education classrooms often become convenient places for teachers to send struggling students they don't want in their classrooms. - US News and World Report, quoted from Shapiro, Loeb, \& Bowermaster, 1992, p. 49 stated:

John Ogbu, noted ethnographic researcher and theorist on minority issues, recently

\begin{abstract}
Minority children receive inferior education...through what occurs inside the schools, inside the individual classrooms. Among the mechanisms discovered to affect minority education adversely, none is more important than teachers' low expectations.... (T)oo many minority children are treated as having educational "handicaps." A disproportionate number are channeled into "special education," a pseudonym for inferior education. (Ogbu, 1990, p. 156, emphasis added)
\end{abstract}

The findings of prominent special education researchers have led to similar conclusions (Gottlieb, Alter, \& Gottlieb, 1994).

Public concern about the quality and appropriateness of special education services for minority students in general, and language-minority students in particular, is high. The level of concern has increased with the surge of immigration to the United States since 1980, the largest in American history. Recent data from the National Center for Education Statistics (1994) show a $40 \%$ increase in the number of school-age children in homes where English is not the primary language. Current estimates project that more than 86 million Americans will be of African, Asian, and Latino heritage by the year 2020 (U.S. Department of Commerce, 1990). Although only one in 10 children in U.S. schools in 1982 was Latino, this ratio will approach one in four by the year 2020 (Natriello, McDill, \& Pallas, 1990).

The authors are affiliated with the Eugene Research Institute and the University of Oregon. 
The quotations above, from both the popular press and social science researchers, demonstrate the heated tenor of the discussion. To date, the scant research on limitedEnglish-proficient students by special educators often focuses on students placed in special education who never should have been there (Figueroa, 1989; Ruiz, 1989; SchiffMyers, Djukic, McGovern-Lawler, \& Perez, 1994).

Yet, Baca and Almanza (1991) estimated that close to one million language-minority students also have a learning disability. That number surely will increase in the years ahead. Some of these students are at risk of receiving no special services or assistance at all (Fradd \& Weismantel, 1987; Gersten \& Woodward, 1994a). Others receive services that are too limited-either instruction designed to assist them with English as a second language provided by a teacher without any understanding of effective strategies for students with learning disabilities (Baca \& Almanza, 1991; Campbell, Gersten, \& Kolar, 1994) or instruction from a teacher trained in special education but with no background in second-language acquisition and no knowledge of a language other than English.

In this article we attempt to delineate effective in-

\section{FOCus on Exceptional children}

ISSN 0015-511X Focus on Exceptional Children (USPS 203-360) is published monthly except June, July, and August as a service to teachers, special educators, curriculum specialists, administrators and those concerned with the special education of exceptional children. This publication is annotated and indexed by the ERIC Clearinghouse on Handicapped and Gifted Children for publication in the monthly Current Index to Journals in Education (CIJE) and the quarterly index, Exceptional Children Education Resources (ECER). It is also available in microfilm from University Microfilms International, Ann Arbor, MI 48196. Subscription rates: individual, $\$ 30$ per year; institutions, \$40 per year. Copyright (C) 1994, Love Publishing Company. All rights reserved. Reproduction in whole or part without written permission is prohibited. Printed in the United States of America. Second class postage is paid at Denver, CO. POSTMASTER: Send address changes to:

Love Publishing Company

Executive and Editorial Office

1777 S Bellaire Street

Denver, CO 80222

Telephone: 303-757-2579

\section{EDITORIAL BOARD}

Edward L. Meyen University of Kansas
Glenn A. Vergason Georgia State University

Richard J. Whelan

University of Kansas Medical Center

Holly T. Rumpler Senior Editor struction for culturally and linguistically diverse students who have difficulty in school, regardless of placement. A good deal of evidence suggests that labeling is arbitrary (Baca \& Almanza, 1991; Mercer \& Rueda, 1991). Our goal is to move beyond the labeling issue and discuss instructional strategies and techniques that are likely to enhance these students' learning irrespective of whether they are formally placed in special education.

\section{THE NEED TO DEVELOP EFFECTIVE INSTRUCTIONAL INTERVENTIONS}

Much of the research on bilingual education for students with learning disabilities has been concerned with placement and referral issues (Figueroa, 1989; Mercer \& Rueda, 1991; Schiff-Myers, Djukic, L, McGovern-Lawler, \& Perez, 1994). Awareness is growing, however, that research must go beyond establishing valid assessment and placement procedures and move toward developing viable instructional strategies for this unique group of students (OSEP Language Minority Researchers' Conference, 1992). Recently Artiles and Trent (1994) noted that "less emphasis on the medical model [of assessment] and more on the quality of instruction would have helped to redirect and strengthen special education service delivery" (p. 416, emphasis added).

Another strand of research has passionately documented persistent problems in current practice, within special education and mainstream classrooms alike. For example, Wilkinson and Ortiz (1986) found that after three years of special education instruction the achievement level of limited-English-proficient students with learning disabilities remained virtually unchanged, and their measured IQ scores actually dropped. Reyes' (1992) naturalistic research documented how Latino and Hmong students failed to develop their potential as writers and readers when they were presented with a language arts curriculum that was not modulated to meet their needs. Moll and Diaz (1987) reported that language-minority students taught by an untrained monolingual teacher with a basal curriculum failed to learn virtually anything, in part because the teachers often treated them like slow learners, when in reality they often knew the answers but could not express them fluently in English.

Although these critiques have served an important purpose, we also need to describe, document, and evaluate practices that succeed. Only recently has an empirical research base on effective instructional interventions for language-minority students started to emerge (Carter \& Chatfield, 1986; Dianda, Madden, \& Slavin, 1993; Goldenberg \& Gallimore, 1991; McConnell, 1989).

Delineation of effective practices for work with culturally and linguistically diverse students has been difficult 
because of the enormity and complexity of the issues. We also believe that until recently governmental agencies have put limited resources into this endeavor (National Advisory Council on Bilingual Education, 1987; OSEP Language Minority Researchers' Conference, 1992). Finally, several deep conceptual problems underpin the field.

To conceptualize how to provide quality services to culturally and linguistically diverse students who need special education, or are otherwise at risk for school failure, one must grapple with and understand the critical issues, controversies, and debates surrounding the education of minority students in general. Gersten and Woodward (1994a) linked several tensions to much of the confusion and misunderstanding underlying the field of special education for language-minority students:

1. The tension between divergent philosophies and theories of bilingual education.

2. The tension between those who argue for a structured approach (in which students' skills and language abilities are developed systematically) versus those who argue for more loosely structured, whole language or constructivist approaches toward building language competence and literacy. (Although each should be treated as a separate issue, they do merge in reality, as will be seen.)

3. The tension caused by the vast distance, in terms of language, culture, social, and instructional norms, that separates so many of these students and their teachers, be they special educators or general educators.

A major purpose of this article is to explore the development of promising practices for culturally and linguistically diverse students in special education and for students at risk for school failure. In this article we discuss the recurrent tensions in special education services for languageminority students articulated by Gersten and Woodward (1994a) and expand the discussion to include cross-cultural tensions. These discussions, then, provide a conceptual framework for understanding crucial aspects of effective instructional practice. Finally, we describe an array of promising practices for low-performing, culturally and linguistically diverse students, culled in large part from our own three-year research project (Gersten \& Jiménez, 1994; Gersten \& Woodward, 1994b), incorporating findings from other contemporary researchers (Arreaga-Mayer, 1992; Au, 1992; Goldenberg, 1992/1993; Reyes, 1992; Yates \& Ortiz, 1991).

\section{A COMPLEX ARRAY OF ISSUES}

As cultural and linguistic diversity expands in American society, traditional educational procedures and traditions no longer fulfill their intended purposes. Confronted with struggling language-minority students, and baffled by their slow and seemingly unpredictable academic progress, teachers often turn to special educators for assistance.

How much help special education can offer, however, is unclear because the vast majority of special educators are monolingual and untrained in second language learning. Often these teachers are uncertain about how to determine whether students have problems because of learning disabilities or because of their limited comprehension of the English language. Yet, as Gottlieb, Alter, and Gottlieb (1994) commented, "The current state of...education [for low-income minority students], so woefully underfunded relative to its needs, provides students little access to intensive resources outside of special education" (p. 459).

To discuss the array of issues confronting the field of bilingual special education, this section will cover:

- assessment and classification issues.

-issues of referral to special education.

-cultural issues.

-models of instruction for language-minority students.

\section{Assessment and Misclassification}

The referral process to special education for culturally and linguistically diverse students has received enormous attention (Figueroa, 1989; Schiff-Myers et al., 1994). Much of this literature has criticized use of standardized procedures and has led some to search for a significantly less flawed assessment system (Baker \& Good, 1994; Rueda, 1994; Yates \& Ortiz, 1991). Many have noted that few relevant measures even exist (Figueroa, 1989) and that traditional assessment measures have serious problems with validity (Garcia, 1991; Lacelle-Peterson \& Rivera, 1994).

A recent trend has been to compare culturally and linguistically diverse students to students from similar countries of origin rather than to mainstream students. Although this is a positive trend, it still can be problematic. Psychologists and teachers may assume incorrectly that all children from the same cultural and linguistic backgrounds can be compared validly to each other (Moecker, 1992). These children, however, often come from a wide range of experiences (e.g., length of stay in the U.S., parents' language skills, refugee experiences), and such comparisons may be misleading (Jacobs, 1991).

Gottlieb, Alter, and Gottlieb (1994) cogently articulated many inherent problems with assessment and classification procedures for culturally and linguistically diverse students:

First, because poverty and race/ethnicity covary, the widespread practice of classifying students hampered by social, cultural, and economic inequities diminishes the credibility of the entire assessment system and renders it vulnerable to accusations of bias and dis- 
crimination.

Second, there could be a "spread effect" in public perceptions regarding the ability of clinicians to classify a child properly for any of the disabling classifications. If "mistakes" are made regarding learning disabilities classifications, perhaps mistakes are also made regarding mental retardation or emotional disturbance classifications.

Third...wholesale eligibility determinations reduce the need for the general education system to develop meaningful instructional programs and services to retain children in the general education classroom. If the vast majority of children who are referred will be removed from the general education class for at least part of the day, there is little incentive to retain them....

Fourth...the well-intentioned classification practices...may actually result in harm to low-achieving children who, although not learning disabled, are placed in special classes from which few ever emerge, which do not produce meaningful gains in children's reading performance, and from which dropouts during adolescence are overly abundant. (p. 459)

Cummins (1991) trenchantly criticized the use of standardized procedures on the basis of their orientation: "If the psychologist's task (or role definition) is to discover the causes of a minority student's academic difficulties and the only tools at his or her disposal are psychological tests (in either the primary or the second language), then it is hardly surprising that the child's difficulties are attributed to psychological dysfunctions" (p. 116). He proposed, as a result, that "professionals involved in assessment become advocates for minority students by focusing primarily on the ways in which students' academic difficulty is a function of interactions within the school context rather than legitimizing the location of the 'problem' within students" (p. 113). Cummins argued for an advocacy approach to assessment that encompasses an understanding of the "disabling of minority students that takes place in classrooms" (p. 116).

A series of observational studies (Arreaga-Mayer, 1992; Gersten \& Jiménez, 1994; Gersten \& Woodward, 1994b; Mehan, Hertweck, \& Meihls, 1986; Moll \& Diaz, 1987) has documented the prevalence of this "disabling" process. Unlike Cummins, however, we believe that a successful advocacy approach must understand not only the instructional and social needs of students but also the needs of those who teach them.

\section{Overreferral or Underreferral: A Seeming Paradox}

Many in the field (see Gersten \& Woodward, 1994b) have addressed the seeming paradox of overrepresentation of culturally and linguistically diverse students in special education in some communities and underrepresentation in others. This continues to be a serious and complicated issue. Although on a national level evidence continues to show overreferral of limited-English-proficient students into special education (Figueroa, 1989; Mercer \& Rueda, 1991; Ortiz \& Garcia, 1988), in certain urban districts a fear of legal action, as well as the realization that assessment procedures for these students are of weak validity, has led to a tendency toward underreferral of these students for any type of support services (Baca \& Cervantes, 1989). In other districts lack of services or personnel knowledgeable in second language issues has resulted in some teachers not bothering to refer students who may be in need of special services. This phenomenon seems to be increasingly widespread for bilingual special education students (Fradd \& Weismantel, 1987; Gersten \& Woodward, 1994b).

Data from the state of Florida compiled by Fradd \& Weismantel (1987) provide a compelling illustration of the underrepresentation of limited-English-proficient students in special education in a state with a relatively long history of providing some type of special services for bilingual students. These data, presented in Table 1, are based on the percentage of students identified as limited-Englishproficient, not the full proportion of language-minority students in the state. Many of the language-minority students who spend their entire school careers in the United States tend to be classified as limited-English-proficient only in the primary grades and often lose that classification in grades $4,5,6$, or 7 , so this would be a somewhat younger sample of children than the full statewide sample. Because the bulk of special education referrals occur after second grade, one would expect the percentage of limited-Englishproficient (LEP) students in the various special education categories to be somewhat lower than in the general population.

The magnitude of the difference is quite strong. For example, $4.2 \%$ of school-age children in Florida were classified as learning disabled, a figure close to the national average of $4.7 \%$ (Singer \& Butler, 1987). Yet less than $1 \%$ of LEP students were classified as learning disabled. A similar phenomenon is found for the mental retardation category. Although $1.6 \%$ of Florida's students are so classified (virtually identical to the national average of $1.7 \%$ ), only $.3 \%$ of the LEP students were classified with mental retardation.

Some (Gartner \& Lipsky, 1987; Gottlieb et al., 1994; Stainback \& Stainback, 1991) would argue that this is a benefit and that these students are spared the "second class education" that special education often provides. Yet our observational research (Campbell et al., 1993; Gersten \& Woodward, 1994a) and naturalistic studies by others (Moll \& Diaz, 1987; Mehan et al., 1986; Ruiz, 1989) reveal that far too many language-minority students with clear learning 
TABLE 1

Comparison of Limited-English-Proficient Students Receiving Special Education Services in Florida with National Special Education Incidence Data

$\begin{array}{lccc}\text { Percent of LEP } & \begin{array}{c}\text { Percent of All } \\ \text { Students Classi- } \\ \text { fied (Florida) }\end{array} & \begin{array}{c}\text { Students Classi- } \\ \text { fied (Florida) }\end{array} & \begin{array}{c}\text { Percent of Stu- } \\ \text { dents Classified } \\ \text { (Nationally) }\end{array} \\ \text { Total Receiving Special Education Services } & 3.10 & 10.59 & 10.97 \\ \text { Learning Disabilities } & 0.94 & 4.16 & 4.73 \\ \text { Speech Impairment } & 1.60 & 3.47 & 2.86 \\ \text { Mental Retardation } & 0.31 & 1.61 & 1.68 \\ \text { Serious Emotional Disturbance } & 0.12 & 1.05 & 0.95 \\ \text { Severe Impairments } & 0.08 & 0.31 & 0.75\end{array}$

Percentages based on 1986 figures

problems simply are ignored or are provided with cursory tutorial services, often by a paraprofessional.

In no way are higher referral rates into special education classes and programs a remedy, but the large number of language-minority students "falling through the cracks" is a major concern. Observational research (Arreaga-Mayer, 1992; Campbell et al., 1993; Chang, 1992) is beginning to document the dire plight of low-achieving languageminority students in general education classrooms that do not modulate instruction.

\section{Cultural Differences and the Challenges Facing Mainstream Teachers}

In addition to decrying the placement of so many minority students in special education, Ogbu (1990) provided some insights into the reason so many minority students do not benefit from conventional instruction and are considered (often inappropriately) for special education placement:

Problems that arise from cultural and language differences are inadequately attended to. The failure of school personnel to understand the cultural behaviors of minority children often results in conflicts that affect the children's capacity to adjust and learn. (p. 156)

Moll and Diaz's (1987) ethnographic research of reading instruction for language-minority students in the "low ability" group raised a host of important issues. Monolingual teachers' focus on the details of accurate English language production made the students appear less competent and able than they really were. The observed teachers tended to correct pronunciation errors (e.g., seyd for said) or interrupted with attempts to define simple English words, and, in so doing, broke the flow of the story.
Moll and Diaz noted "the deliberate, slow pace of lessons with students in the low reading groups" (p. 305) and the lack of intellectual challenge and conceptual development provided by monolingual teachers.

When Moll and Diaz followed the "low ability" students into a Spanish reading lesson, they observed that these same students were able to answer comprehension questions correctly and to develop and expand on ideas in the stories. Their observations of these students in conventional English language classrooms highlight some of the problems that arise when teachers attempt to apply traditional principles of instruction and assessment to seemingly low-performing language-minority students. They noted that students' capacities often are underestimated and thus they are subjected to incessant drill on skills they have already mastered in Spanish but cannot convey fully in English. They rarely are afforded opportunities to discuss ideas and complex concepts, apply principles, or experiment with implications of ideas.

Observational research we and our colleagues (Gersten \& Jiménez, 1994; Gersten \& Woodward, 1994a) conducted found numerous instances of what we called "lost opportunities." For example, in three different classrooms the issue of old clothes came up in the assigned novels. In each case the main character of the story, who was poor, was ashamed to attend a party because she had only old clothes. The teacher in each of these classrooms seemed overwhelmed by the issue of how to discuss poverty, knowing full well that many of his or her students often wore handme-down clothes. Nieto (1992) dubbed this phenomenon "the fear of naming." Although Nieto focused her discussion on issues of race and ethnicity, it can be applied to social class as well.

The teachers we observed seemed temporarily upset by this rather naked invasion of real world social class issues. They shied away from the issue by awkwardly telling the 
students how to think rather than inquiring as to what the students felt and thought. The teachers talked about how they sometimes wear old clothes, that there is nothing wrong with wearing old clothes, and the character really shouldn't have felt ashamed. Observing these awkward encounters, we were left with the sense that the teachers had shied away from meaningful encounters with their students and from a serious use of literature to help students understand the various dimensions of their lives.

What the teachers provided actually was counterproductive to understanding the novels. Each novel focused on a girl's shame and humiliation at being the only one at the party with old clothes. Old clothes clearly mean something very different to a lower-class person and a middle-class person. As the teachers attempted these uncomfortable explanations about why wearing old clothes is all right, the students often looked puzzled. The desire by many mainstream teachers to maintain the illusion of egalitarianism, contradicted every day by these students' life experiences, may have motivated the "fear of naming." The tension and discomfort in these classrooms were obvious.

In contrast, two of the teachers observed did not sidestep the issue of poverty when it came up. These teachers asked students to write about broken-down television sets and broken-down trucks and to describe their thoughts and feelings regarding the impact of these events on their lives. These teachers allowed the students to express their perspective on the issues or events, maintaining the integrity of each experience.

Although merely allowing free expression of not-sopleasant experiences is hardly a panacea for the complex tasks facing teachers, it does serve as a basis for beginning to break down barriers. Our observations have shown consistently that when teachers allow for breaking down barriers, students become less reticent.

One of the most perceptive discussions of the issues and problems facing those who teach language-minority students is provided by McElroy-Johnson (1993), an African-American teacher of minority students (Asian, AfricanAmerican, and Hispanic) in the Oakland Unified School District. Her eloquent article in the Harvard Educational Review attempts, in her words, to "give voice to the voiceless."

McElroy-Johnson noted that "some teachers...teach to a curriculum as if it were set in stone.... [They] maintain a distance that borders on indifference" (p. 98). She proceeded to link this distance, this disengagement between teachers and students, to the "chasms of failure" into which so many minority students fall. We observed this type of disengagement in an interview with a teacher who wistfully remarked, "There are days when I don't think what I do makes much difference to these kids. They have so many other things to deal with in their lives. Some days I don't think anything that I do ever gets through. But there are other days when I feel that if I at least teach the basics, at least I've done something" (Gersten \& Woodward, 1994b). This teacher's conception of the basics was a dreary diet of vocabulary drill, grammar, and punctuation, day after day.

McElroy-Johnson's analysis indicates the need for high teacher expectations and explicit instruction based on accurately assessed learner performance in all academic areas, not just grammar and punctuation. In this sense, her writings parallel the empirical findings of researchers such as Brophy and Good (1986), Ysseldyke, O'Sullivan, Thurlow, and Christenson (1989), and Carnine (1991), but she added another critical component often missing from these earlier syntheses:

They need challenges, and teachers must maintain high standards and expectations for them. They need...ways of dealing with pent-up emotions resulting from living in a society that has not valued them. Teachers who refuse to deal with these issues are leaving these students voiceless....

Our students come to us with a great deal of confusion, from many different backgrounds, cultures, races, and socioeconomic situations. They are confused and frightened, and often can't express their own opinions.... They need and want direction. (pp. 100101, emphasis added)

Helping teachers provide this type of direction to their students is critical. Pleas for teachers to "celebrate diversity," to watch their students closely to learn from them, or to use teaching as a venue to learn about themselves and their biases (Greene, 1993), however well intentioned and relevant for some seasoned practitioners, often fail to help inexperienced teachers who are struggling with basic issues in curriculum and management (Carter \& Richardson, 1989). Similarly, courses in theories of second language acquisition are not particularly useful unless they provide a wide range of concrete instructional examples.

The urban teachers we interviewed expressed a real need for concrete strategies they can use to break down existing barriers and teach effectively. The issue of how to develop realistic means to assist educators from mainstream, middle-class backgrounds in addressing the needs of culturally and linguistically diverse students is being broached only slowly in a pragmatic fashion. The observational research of Reyes (1992) and the work of other minority educators such as Delpit (1988) and McElroy-Johnson (1993) provide information that can be relevant to these teachers' needs. All of this research has in common a call for mainstream educators to listen to members of minority communities and to not assume that any approach or method is capable of meeting the needs of minority students without 
authentic dialogue and meaningful interaction with members of those communities.

\section{Differing Approaches and Conceptions of Second Language Instruction}

The type of bilingual program model used and the language of instruction, while important, have received far more attention in research and public debate than the equally critical issue of how ideas and concepts are taught (see Crawford, 1989, and Cziko, 1992, for an expanded discussion of bilingual program models). Plagued by problems of research design, program evaluation studies consistently have failed to determine which of the two approaches is better.

In retrospect, to assume that a particular approach to bilingual education in and of itself could counteract the influences of poverty and discrimination was naive. Regardless of the year in which English language reading instruction was introduced, many of the low-income Latino students in these evaluations scored in the 20th to 30th percentile. This indicates a need to look more deeply at the quality of instruction provided to the students and the level of support given to their parents. For example, Ramírez (1992) noticed infrequent use of higher-order questions and limited opportunities for extended discourse in either Spanish or English in any of the bilingual program models. Clearly, these factors contribute to the consistently low levels of performance. With this perspective we briefly review two of the main approaches (native language and sheltered English) toward bilingual education currently in use in this country.

\section{Native Language}

The rationale for native language emphasis was articulated by Wong-Fillmore and Valdez (1986): "It is not possible to read in a language one does not know... if reading involves the act of making intelligible to oneself written texts of any complexity beyond that of street signs. A prerequisite for true reading, it would appear, is a fairly high level of knowledge of the language in which the text is written" (pp. 660-661). Hakuta and Snow (1986) argued that information and abilities learned via students' native language can be transferred to learning in English: "The child who knows how to write a topic sentence or look up a word in the dictionary in Portuguese or Chinese will have these skills available for use in the English classroom" (p. 18). Therefore, teaching complex academic content to students in their native language first seems sensible so students can understand and discuss challenging material without the added demand of constantly translating or expressing ideas in a second language.
A problem with prematurely placing students in academic classes taught in English is that the academic material will be simplified or "watered down." "A common reaction to the less-than-fluent English of a student is to teach content from a lower grade level and to expect only lowerlevel cognitive skills, such as simple recall" (Chamot \& O’Malley, 1989, p. 114).

\section{Sheltered English}

Sheltered English introduces English more rapidly. It is taught, in large part, through reading and content-area instruction. A rationale is provided by Anderson and Roit (1993): "Spoken language is fleeting and inconsistent over time. Text is stable and does not pass the learner by. It allows one to reread and reconsider that which is to be learned in its original form" (p. 2).

The goal of sheltered English is for students to learn English while they develop academic and cognitive abilities in areas such as comprehension and problem solving. Merging English language instruction with systematic instruction in social studies and science (Chamot \& O'Malley, 1989; Gersten, Taylor, \& Graves, in press) can accelerate academic/conceptual English language vocabulary.

Skillful and sensitive implementation of either approach requires attention to the concept of comprehensible input. For lessons to be comprehensible to students for whom English is a second language, the complexity of the English language vocabulary used must be constantly and sensitively modulated (Long, 1983) based on students' responses (or their failure to respond).

Although great diversity of opinion and practice remains as to how rapidly students should be introduced to English language instruction and how long native language instruction should be maintained (Chamot \& O'Malley, 1989; Crawford, 1989; Gersten \& Woodward, 1994b; Ramírez, 1992), one thing seems certain: Abrupt transitions from virtually all-Spanish to virtually all-English instruction are often detrimental to students (Berman et al., 1992; Ramírez, 1992). During the transition years teachers often are unable to help students use the cognitive abilities and knowledge developed during the years of native language instruction. It's almost as if some students are asked to begin schooling anew in the fifth or sixth grade. This can be especially problematic for students who have academic difficulties.

\section{A NEED FOR MEANINGFUL COLLABORATION}

Recently research has shifted from searching for the "best" program model or documenting the shortcomings of existing approaches and toward identifying useful and feasible instructional practices (Berman et al., 1992; Hakuta, 
1986; Reyes, 1992; Tikunoff, 1985). Pugach and Warger (1993) called for collaboration between special and general educators in the redesign of curriculum for diverse learners:

\begin{abstract}
Students identified as having learning disabilities are not the only ones who are unable to keep up with the standard, lock-step curriculum. Many others also have difficulty achieving basic literacy and numeracy. Large numbers of students who are members of racial, ethnic, or linguistic minorities... are included in the growing list.... A curriculum based on the assumption that most children come to school ready to learn, with some rudimentary knowledge of the alphabet and prereading skills like knowing how to hold a book and employing left-to-right progression, is not easily absorbed [by these students]. (p. 128)
\end{abstract}

As special educators, we have much to contribute. For example, the knowledge bases on cognitive strategy instruction (Bos \& Anders, 1990; Harris \& Pressley, 1991) and reciprocal teaching methodologies for effective reading instruction, motivational strategies, and direct/explicit instruction in higher order thinking (Carnine, 1991) all can contribute to more effective teaching of language-minority students, especially those experiencing difficulty.

Although it is important for ensuring success and academic growth for many students, the task-analytic, skillbuilding approach used in many special education programs is insufficient to fully meet their needs. In the area of language development, growth in English skills may be stifled (Cummins, 1989; Yates \& Ortiz, 1991). Tharp and Gallimore (1988) noted that the attempt to improve reading performance by controlling both oral and written vocabulary and using highly structured phonics progressions-a cornerstone of many special education programs-seemed to impede English language acquisition for limited-Englishproficient students. Tharp and Gallimore offered an eloquent plea for conscious integration of natural language use and genuine dialogue into classroom instruction. An emphasis on correct oral reading, proper pronunciation in English, systematic instruction involving vocabulary lists, and English language grammar and literal comprehension may inhibit the language development of students and also may hinder their overall cognitive development by taking some of the meaning and enjoyment out of learning (Gersten \& Woodward, 1994a).

McElroy-Johnson (1993) illustrated one of the instructional dilemmas teachers face when she argued that appropriate instruction for low socioeconomic status (SES) minority students must simultaneously provide reasonable structures to facilitate learning, explicitly teach necessary academic concepts and skills (including those that many middle-income parents teach their children at home) and allow students a means to express their thoughts and prac- tice and guidance in how to express their ideas and opinions. She focused instruction in large part on discussion and interpretation of literature and development of expressive writing abilities following a framework similar to that proposed by Palincsar (1993) and by Englert (1993).

How rarely this type of focused but sensitive instruction is provided to language-minority students has been documented in the ethnographic research of Reyes (1992), who poignantly described how cross-cultural miscommunications can lead to abject failure. Whereas McElroyJohnson expressed why traditional ways of teaching (e.g., using textbooks or worksheets) will not succeed, Reyes artfully documented how attempts to use whole language or process writing approaches will fail unless the teachers use instructional strategies that make sense for their students. Teachers must use data provided by students to modulate how they teach. She noted:

On the surface the teachers seemed to be doing everything right, yet the exposure to good models of writing, spelling and punctuation did not produce correct writing form or growth in the bilingual students' writing fluency.... At the end of two years, most were still making the same spelling and grammatical errors as in the beginning.... For example, in a journal entry dated September 9th, a student wrote, "My ant is getting married in [sic] Saturday." The teacher responded, "How was your aunt's wedding?" In a subsequent entry, the student again reported on her ant's weddingignoring the correct form modeled by the teacher. In later February...she wrote, "Her mom my ant is a good cook."...One of the teachers said of...her seventh graders, "Students keep making the same errors with spelling, grammar, punctuation, etc. It's frustrating!" (p. 432, emphases added)

Reyes concluded:

The high regard that Hispanics hold for teachers as authority figures (Delgado-Gaitan, 1987) indicates that they rely on and expect direct instructional intervention from the teacher. Many look for it and may not understand it when it comes masked in indirect requests or disguised.... The assumption that error correction hampers students' learning rendered the modeling of correct forms and the indirect nature of the mini lessons ineffective in teaching important literacy skills to linguistically different students. (pp. 439-440, emphasis added)

\section{RECONCEPTUALIZING INSTRUCTIONAL PRACTICES}

Clearly, some reconceptualization of how languageminority students (including those in special education) are taught is necessary-a reconceptualization drawing on the 
developing consensus among bilingual education researchers while integrating principles of effective instruction and newer cognitive approaches from special education. A body of research emerging from these three areas suggests several practices that are likely to be effective.

\section{Constructs for Effective Teaching}

The following outline articulates the key components of effective, comprehensible instruction for languageminority students.

\section{Scaffolding and Strategies}

a. Provide story maps and visual organizers

b. Encourage transfer of native language skills

c. Elicit or provide relevant background knowledge

d. Stress and reiterate underlying big idea with range of examples

\section{Challenge}

3. Involvement
a. Provide extended discourse
b. Use complex linguistic structures
c. Foster active engagement of all

\section{Success}

5. Mediation and Feedback
a. Make it frequent and comprehensible
b. Focus on meaning
c. Use recall strategies
d. Ask for supporting evidence

6. Responsiveness to Cultural and Individual Diversity
a. Link content to experience
b. Use personal experience

\section{Comprehensible Input}

Based on extensive work with language-minority students, Barrera (1984) explained how English language reading can be an excellent medium to develop English language competence. Elley and Mangubhai's (1983) work further supports this position. When students learning English were given an abundance of high-interest storybooks in English, their progress in reading and listening comprehension increased at almost twice the usual rate.

Our research has noted that some teachers seem to go overboard with poorly conceived multiculturalism. For example, one must question spending a full month on a novel about the Sioux Indians with a class of students who recently arrived in the United States from Cambodia or Vietnam. Our observations reveal that student motivation tends to decrease with ill-conceived cognitive overload. Logic suggests spending some time using literature to orient these students to the norms and traditions of Seattle or San Francisco in a meaningful way.

Teachers also must elicit or provide relevant background knowledge so material is comprehensible. An emerging view of effective instruction for languageminority students builds on the concept of comprehensible input (Krashen, 1982). Ensuring that students understand what teachers attempt to convey involves intentional redundancy, more simple or declarative sentences, frequent checks for student comprehension, and physical gestures and visual cues. Fradd (1987), however, cautioned that making material comprehensible should not mean watering down concepts. It requires sophisticated modulation of instruction.

Teachers should try to explain ideas or concepts several times, with slight variations in terminology and examples. Unfortunately, examples that link material in the story to students' backgrounds are rarely provided. For example, Gersten and Morvant (1994) noted that a teacher introduced a story about Jewish emigrés from Nazi Germany without explaining anything about the Nazi movement or the Holocaust. Furthermore, the teacher did not attempt to link the experience of the Schumacher family in the story with the migration of one of her students from Cambodia. These lost opportunities were common.

This approach to teaching, which requires balancing systematic strategy and skill development to promote comprehension, is extremely difficult for teachers to implement (Gersten \& Woodward, 1994b). To a large extent, the difficulty stems from the time teachers take to master and personalize these techniques. Teachers need to be sensitive to growth in students' cognitive and English language development over longer periods. Furthermore, teachers must ensure that all students experience academic success daily while also pushing students slightly beyond their current level of knowledge. This combination requires expertise and a series of sophisticated judgments.

To continually modulate and clarify the language of instruction, teaching must also be highly interactive. Teachers must involve students constantly, ask many questions, and encourage students to express their ideas and thoughts in the new language. Comprehensible instruction requires that teachers control their vocabulary carefully and use graphic organizers, concrete objects, and gestures when possible to enhance understanding.

\section{Transfer for Bilingual Special Education Students}

In the context of bilingual education, transfer refers to timely cross-linguistic accessing of information and application for purposes of problem solving. It means recognizing that information learned or experienced in one language is useful for comprehending information or accomplishing a 
task conducted via the other language. Transfer of information, skills, and strategies from one setting to another (e.g., Chapter 1 reading room back to the general education classroom) is often difficult for native-English-speaking students (Allington \& McGill-Franzen, 1989; Prawat, 1992), especially those with learning disabilities (Anderson-Inman, Walker, \& Purcell, 1984; Carnine, 1991; Harris \& Pressley, 1991).

As an instructional concept, transfer holds such strong intuitive appeal for enhancing the academic achievement of bilingual students that theoreticians such as Cummins (1989) invoke its power as the basis for native-language instruction. Cummins popularized the notion that transfer will occur almost automatically if language-minority students receive extensive academic instruction for many years in their native language. Many teachers have understood this to mean that transfer is inevitable after providing students with some native language instruction.

Transfer, however, really is not automatic (Hakuta, 1990). Students frequently need prompting, reminders, and other types of scaffolded interactions to avail themselves of information or skills learned previously. A more contemporary understanding is that transfer can occur after knowledge is acquired via one language or the other, that it operates in both directions (Spanish to English and English to Spanish) but it is not inevitable.

Two points are notable. First, although some students discover on their own how to make connections between what they learn in one language and reading/writing activities in their second language, many clearly do not. Largescale evaluations of bilingual education, though controversial, report consistently that far too many students are performing below acceptable levels by the time they reach middle school, regardless of the type of program (Cziko, 1992; Gersten \& Woodward, in press; Ramírez, 1992). As Hakuta (1990) noted, research must "generate a better understanding of how this [transfer] process occurs, and under what circumstances it occurs most efficiently" (p. 50).

Second, although transfer is possible under certain conditions, it is reasonable to hypothesize that it can be enhanced and encouraged and that strategies can be taught. Thus, instruction and classroom environments that facilitate transfer for children learning English as a second language are a necessity, not a luxury.

Regardless of whether students were enrolled previously in a native-language program, instruction that facilitates transfer should be encouraged. All children have potentially valuable knowledge and experiences that could be drawn on to enhance their learning. All children also have a great deal of information they have gained outside the classroom. Carefully designed instruction that attends to all of the aspects of effective instruction presented earlier is needed to maximize this promising avenue of student learning.

\section{Opportunities for Natural Language Use}

Language-minority students also must be given opportunities to move from learning and producing limited word translations and fragmented concepts to using longer sentences and expressing more complex ideas and feelings (Barrera, 1984). Special educators often have a relatively easy time separating complex concepts into small steps, assessing frequently whether students understand the concept taught, and using redundant language and physical gestures as prompts.

Constricted language often is observed in special education classrooms (Gersten and Woodward, 1994a). It seems to be a logical extension of the training that many special education teachers receive. These teachers' attempts to control curricula and language strictly, however, do not afford the student opportunities for language development. Encouraging students to express their ideas in a new language, and in increasingly complex forms, presents a challenge for special educators. A more natural, fluid learning environment is necessary for language development. People need opportunities to use language to obtain what they want or to express their thoughts, feelings, and ideas (Fradd, 1987).

Goldenberg's (1992/1993) model for developing "an explicit instructional conversation" (p. 3) provides some excellent guidelines for fostering natural language use. Although Goldenberg says it is impossible to use the techniques throughout the entire day, an intensive 20-30 minute focus on language learning and language concepts can be scheduled. He describes instructional conversations as:

instructional in intent-they are designed to promote learning. On the other hand, they are conversational in quality - they appear to be natural and spontaneous language interactions, free from the didactic characteristics normally associated with formal teaching.... Strategically, the teacher (or discussion leader) questions, prods, challenges, coaxes-or keeps quiet. (p. 3)

Another important feature of instructional conversations is that the teacher plays a deliberate role and maintains a self-controlled agenda:

[Students] are pointed toward a learning objective or a goal by the teacher, who must be thoroughly acquainted with the text and the ideas under discussion and with the many possibilities they offer for intellectual exploration, concept development, and the construction of meaning with students. (p. 6)

Clearly, planning is essential for utilizing this tech- 
nique, because the teacher needs to structure the instructional conversations toward a learning objective. Use of instructional conversations also requires many of the constructs for effective teaching, such as:

-providing relevant background knowledge.

- providing frameworks/schema for understanding and a

focus on the main ideas (e.g., "big ideas," story maps).

-involving all students.

—-direct teaching of necessary skills and concepts.

Within this framework conversational elements are incorporated into the lesson structure. The main components of these conversational elements are presented in Figure 1. The following is an example of a teacher utilizing the constructs and principles of instructional conversations:

For example, she asked, "What do you think the story will be about? Do you think this lady will be in the story?" She delicately elicited a wide range of predictions; each prediction was placed on the chart. Unlike other teachers, she returned to each prediction and had the students evaluate them. This level of intellectual accountability, though rare, is crucial.

Student involvement was extremely high. Even the more passive students volunteered a prediction. The

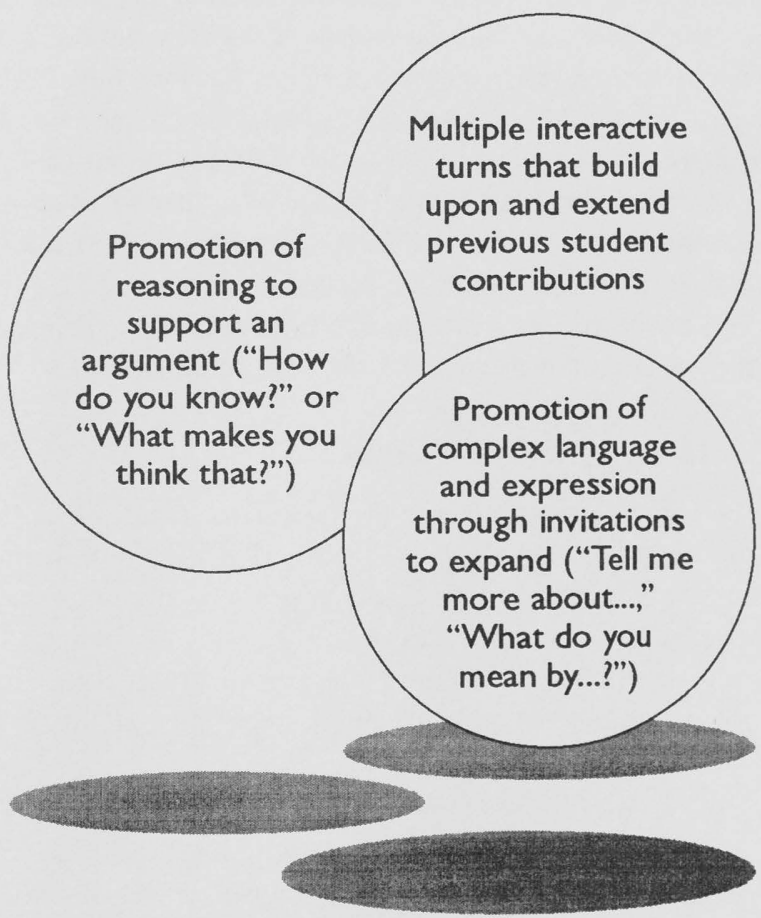

FIGURE 1

\section{Unique Features of Instructional Conversations}

Source: From "Instructional Conversations: Promoting Comprehension Through Discussion," by C. Goldenberg, 1992/93, Reading Teacher, 46(4), 316-326. teacher provided prompts to students who seemed to be floundering, such as: "With a title like this and this picture on the cover, Fernando, what do you think this story will be about?" Her style of feedback and mediation was very interesting. She never judged a response incorrect or illogical. However, when a student predicted that the people in the story "will have a ranch," a statement that seemed to make no sense, she asked him why. When he was unable to answer, she neither praised nor criticized him, she merely moved on. (Gersten, 1993, p. 24)

Another strategy that holds much promise in fostering natural language use for limited-English-proficient students is the cooperative learning group. Small cooperative groups allow students to interact with peers while doing schoolwork assignments. Gersten and Woodward (1994a) observed an example of a cooperative learning situation that allowed for a constructive interaction. A student named Victor, considered at risk for special education referral, was involved in a cooperative learning reading activity:

$(\mathrm{H}) \mathrm{e}$ had the word "nervous" on his sheet. A friend said, "That's wrong. Captain Bill is brave and strong. He never got nervous." Victor opened his book and provided the evidence. The other students found his argument compelling. All put the word "nervous" on their sheets. Thus, in the middle of a fairly mundane activity, there was evidence of genuine reading comprehension and constructive dialogue. [It appeared] that Victor experienced the excitement of winning an argument and convincing others. (Gersten \& Woodward, 1994a, p. 16)

Use of cooperative learning groups with bilingual special education students has been shown to provide some positive benefits, such as:

-creating opportunities to use language in a meaningful and nonthreatening fashion (Baca \& Cervantes, 1989; McGroarty, 1989).

-drawing on primary language skills while developing second language skills, especially if other bilingual students work together (McGroarty, 1989).

- promoting higher-order cognitive and linguistic discourse (Garcia, 1993).

- fostering peer modeling and peer feedback rather than using formal and often embarrassing error-correction procedures.

The teacher's role as facilitator is crucial in guiding groups toward these benefits. Extra support for students with learning disabilities might be needed, as these students may be less likely to adapt to the listener's needs and tend to use restricted forms of language (Ruiz, 1989). Certainly, teachers can foster success for cooperative groups by build- 
ing vocabulary, providing background knowledge, and providing practice with cooperative learning strategies.

Dianda, Madden, and Slavin (1993) noted:

\begin{abstract}
Studies of schools and classrooms where languageminority students have been particularly successful academically report that individual instructional activities and individual competition among students were limited.... Classrooms were lively and even noisy environments in which students collaborated with each other in small groups to complete assignments. (p. 5)
\end{abstract}

In the "Success for All Program," which utilizes cooperative learning groups, Dianda, Madden, and Slavin documented the positive benefits for students from lowincome backgrounds. Currently, they are evaluating the program's expansion for language-minority students. Given that cooperative learning groups provide many natural language contexts, further exploration of this method for language-minority special education students could be useful.

\section{Bridging with Families}

Home-school collaborations are becoming more important as a means of improving education for culturally and linguistically diverse students (Goldenberg \& Gallimore, 1991; Ruiz, 1989). Research also is beginning to show the potential role of siblings (Campbell et al., 1993; Keating, 1993), whose knowledge of English, as well as knowledge of relevant aspects of the community, often surpasses that of their parents. This represents a valuable resource to school personnel.

School staffs' assumptions about students' families often hinder home-school communications (Goldenberg \& Gallimore, 1991). Assumptions that parents do not value academic achievement result in minimal attempts by school staff to build home-school collaborations. Parents typically are contacted only when problems arise or when grade-level retention is being considered. Often, families are not contacted for involvement until the referral to special education is made. Yet, during the prereferral process, family involvement is critical, especially for language-minority students. Not only can family members provide valuable information regarding a student's language skills, behaviors at home, and school background, but they also may offer a unique perspective on the nature of the student's difficulties. Furthermore, they can provide the additional assistance a student may require, by reinforcing school concepts at home and monitoring homework.

Only recently have schools (often in conjunction with researchers) begun to develop systems by which teachers can communicate information on student progress (successes and problems alike) and impart to parents expec- tations for homework, along with specific ways for parents to help their children even if the parents' English is weak (Goldenberg \& Gallimore, 1991; Harry, Torguson, Katkavich, \& Guerrero, 1993). Although this work is in its infancy, it seems to have enormous potential.

Simply informing Latino parents of their children's difficulties in school can bring about qualitative changes in student performance (Goldenberg, 1987). Homework featuring regular practice and reinforcement of what was learned at school, along with systematic follow-up by teachers, resulted in more effective family involvement (Goldenberg \& Gallimore, 1991). Teachers in this study sent home simple texts to be read at home, writing practice sheets, and "cumulative word lists" to read at home. Parents signed for completed assignments, which were returned to the teachers the following day. The focus was on an agreed-upon goal of parents and teachers: to increase student literacy skills. Delgado-Gaitan (1990) helped Latino parents understand the school system through parent action committees, facilitating communication between the home and schools.

These attempts certainly help reduce the distance between teachers, students, and families from different cultural and linguistic backgrounds. Through community, school, and family networks, teachers of culturally and linguistically diverse students can begin to understand and work together to meet the diverse needs of these students. In our own research (Gersten \& Jiménez, 1994) we have found that parents often have fascinating insight into the abilities, personalities, and potentialities of children identified by their teachers as at-risk for placement in a special education classroom. Parents should be included in decisions affecting their children, both on ethical/professional grounds and because their help can save valuable time and allow better direction of resources to areas of real academic need.

\section{SUMMARY AND CONCLUSIONS}

A fairly recent article in the New York Times was titled simply "Hispanics in Despair" (Suro, 1990). One indication of the dire plight of Latino students in the American educational system is that approximately $35 \%$ of all Latino students discontinue their education before completing high school, a figure that has remained stubbornly at this level for more than 15 years (Waggoner, 1991).

We hasten to add that the magnitude of the problem often has been understated. More and more children are entering school from low-income homes. Issues of family income level and ethnicity, and their potential impact on school learning, cannot be isolated (Gottlieb et al., 1994; Natriello et al., 1990; Teale, 1986). Too high a proportion of students enter school with low exposure to literacyrelated activities in any language. And forces continue to put culturally and linguistically diverse students at a disad- 
vantage, evidenced by high dropout rates, low achievement, and the high incidence of referral to special education.

Exactly how the field of special education can assist in addressing the deep-rooted systemic problems that confront so many culturally and linguistically diverse students and their teachers is uncertain. Nonetheless, we believe some directions can be articulated.

A reconceptualization of special education services is necessary, as many culturally and linguistically diverse students are further handicapped by their placement in special education programs. As mentioned at the beginning of this article, public criticisms of special education have to be addressed. Clearly, special education has not succeeded in providing students the hoped-for remedies and support necessary for academic success. Special educators should be involved in examining school practices and policies and evaluating how these practices affect student learning. Although some culturally and linguistically diverse students who require educational support may not be receiving any assistance, the issue of classification is probably not the key factor in improvement efforts. Rather, flexibility of services and effective prereferral interventions may address the needs of many culturally and linguistically diverse students in the general education setting.

Although interest in instructional issues for culturally and linguistically diverse students has increased, the need persists for collaborative exchanges among general educators, special educators, and bilingual educators. The areas of curriculum design and instructional strategies, in particular, can contribute much to quality learning environments for culturally and linguistically diverse students who continue to struggle with the education currently provided them.

Many challenges remain. For example, should a student with disabilities receive core reading instruction in the native language (which will be appreciably less frustrating), with the hope of some future transfer, or in English, where, despite initial frustration, transfer will be less of a problem?

The quality and quantity of appropriate personnel is another complex issue. The shortage of trained bilingual special educators is extreme, and the dramatic increase in the proportion of second language students in the schools is not paralleled by an increase in bilingual teachers, in either special or general education (Baca \& Almanza, 1991). Furthermore, the increasing multiplicity of language groups in the schools puts additional stress on the system. Knowledge of only one language other than English is, in many situations, insufficient to meet the needs of all students.

Effectively teaching culturally and linguistically diverse students, both within and outside of special education, is vital for the field of education. Although few special educators currently possess adequate knowledge of all aspects of this task, the field has much to offer, and this knowledge will be required to provide more assistance in this area.

Yates (1993), president of CEC's Division of Culturally and Linguistically Diverse Exceptional Learners, declared: "An educational professional does not necessarily have to belong to the same cultural and linguistic community as the student to be an effective service provider" (p. 1). He noted that all special education personnel, "regardless of their own ethnolinguistic background, must be trained to effectively serve a multicultural student population" (p. 3). And, like Yates, we believe the development of effective strategies for this extremely large group of students is a shared responsibility.

How much can be extrapolated from research with mainstream students with learning disabilities remains unclear. The tasks facing low-income, language-minority students with disabilities are daunting: mastering a new language and developing literacy in two languages. Our observations reveal that some of these students have difficulty with the pace of mainstream ESL instruction, yet schools tend to do little in this area because it is not a typical domain for special education. In our view, however, it is clearly a domain where even monolingual special educators, who often have a background in oral language development, can provide needed services.

As we have indicated throughout this article, the relative emphasis that special educators should place on intrinsic versus extrinsic motivation - on skill development versus viewing literacy as a means to communicate with others-is still unclear. Although the tendency is to encourage instructional approaches that try to build intrinsic motivation for culturally and linguistically diverse students (Garcia, 1993; Ruiz, 1989), no data exist to either support or refute the efficacy of this approach.

As we attempt to understand effective practices for culturally and linguistically diverse students, a focus on the quality of instruction should promote practices that directly affect student learning. Collaboration-among special educators, with their knowledge of systematic skill building, general educators' knowledge of process approaches, and bilingual educators' knowledge of language acquisition techniques - offers opportunities for merging effective elements to achieve balance in instructional practice. Only with this type of collaboration and sharing of expertise will techniques be developed that succeed with all students. Along with this type of balance in instruction, opportunities to learn meaningful content, or, in the eloquent words of McElroy-Johnson (1993), "giving voice to the voiceless," is critical to closing the distance between students and teachers.

\section{REFERENCES}

Allington, R., \& McGill-Franzen, A. (1989). School response to 
reading failure: Instruction for Chapter 1 and special education students in grades two, four and eight. Elementary School Journal, 89(5), 529-542.

Anderson, V., \& Roit, M. (1993). Reading as a gateway to language for primary students of limited English proficiency. Manuscript submitted for publication.

Anderson-Inman, L., Walker, H. M., \& Purcell, J. (1984). Promoting the transfer of skills across settings: Transenvironmental programming for handicapped students in the mainstream. In W. L. Heward, T. E. Heron, D. S. Hill, \& J. Trap-Porter (Eds.), Focus on behavior analysis in education. Columbus, $\mathrm{OH}$ : Charles E. Merrill.

Arreaga-Mayer, C. (1992, August). Using ecobehavioral assessment to evaluate effective bilingual special education programs. In Proceedings of the Third National Research Symposium on Limited English Proficient Student Issues: Focus on Middle and High School Issues (pp. 763-797). Washington, DC: U.S. Department of Education, Office of Bilingual Education and Minority Language Affairs.

Artiles, A. J., \& Trent, S. C. (1994). Overrepresentation of minority students in special education: A continuing debate. Journal of Special Education, 27(4), 410-437.

Au, K. (1992, April). Student purposes in peer- and teacherguided literature discussions. Paper presented at the annual meeting of American Educational Research Association, San Francisco.

Baca, L. C., \& Almanza, E. (1991). Language minority students with disabilities. Reston, VA: Council for Exceptional Children.

Baca, L. M., \& Cervantes, H. T. (1989). The bilingual special education interface (2nd ed.). Columbus, $\mathrm{OH}$ : Merrill.

Baker, S. K., \& Good, R. (1994). The reliability and validity of a direct and frequent measure of English reading fluency for Hispanic students who are bilingual. Unpublished manuscript, University of Oregon, Eugene.

Barrera, R. (1984). Bilingual reading in the primary grades: Some questions about questionable views and practices. In T. H. Escobar (Ed.), Early childhood bilingual education (pp. 164183). New York: Teachers College Press.

Berman, P., Chambers, J., Gandara, P., McLaughlin, B., Minicucci, C., Nelson, B., Olson, L., \& Parrish, T. (1992). Meeting the challenge of language diversity: Vol. 1. Executive summary. Berkeley, CA: BW Associates.

Bos, C. S., \& Anders, P. L. (1990). Interactive teaching and learning: Instructional practices for teaching content and strategic knowledge. In T. E. Scruggs \& B. Y. L. Wong (Eds.), Intervention research in learning disabilities (pp. 166-185). New York: Springer-Verlag.

Brophy, J., \& Good, T. L. (1986). Teacher behavior and student achievement. In M. Wittrock (Ed.), The third handbook of research on teaching (pp. 328-375). New York: Macmillan.

Campbell, J., Gersten, R., \& Kolar, C. (1993). The perplexities of providing quality instruction to language minority students with learning disabilities: Five findings from microethnographies (Technical Report 93-5). Eugene, OR: Eugene Research Institute.

Carnine, D. W. (1991). Curricular interventions for teaching higher order thinking to all students: Introduction to the special series. Journal of Learning Disabilities, 24(5), 261-269.

Carter, K., \& Richardson, V. (1989). A curriculum for an initialyear-of-teaching program. Elementary School Journal, 89(4), $405-420$.
Carter, T. P., \& Chatfield, M. L. (1986). Effective bilingual schools: Implications for policy and practice. American Journal of Education, 95(1), 200-232.

Chamot, A. U., \& O’Malley, J. M. (1989). The cognitive academic language learning approach. In P. Rigg \& V. Allen (Eds.), When they don't all speak English (pp. 108-125). Urbana, IL: National Council of Teachers of English.

Chang, J. M. (1992, August). Current programs serving ChineseAmerican students in learning disabilities resource issues. In Proceedings of the Third National Research Symposium on Limited English Proficient Student Issues: Focus on Middle and High School Issues (pp. 713-736). Washington, DC: U.S. Department of Education, Office of Bilingual Education and Minority Language Affairs.

Crawford, J. (1989). Bilingual education: History, politics, theory and practice. Trenton, $\mathrm{NJ}$ : Crane.

Cummins, J. (1989). A theoretical framework for bilingual special education. Exceptional Children, 56 (2), 111-119.

Cummins, J. (1991). Empowering culturally and linguistically diverse students with learning problems (EDO-EC-91-5). ERIC Digest.

Cziko, G. A. (1992). The evaluation of bilingual education. Educational Researcher, 21(2), 10-15.

Delgado-Gaitan, C. (1987). Mexican adult literacy: New directions for immigrants. In S. R. Goldman \& H. T. Trueba (Eds.), Becoming literate in English as a second language (pp. 9-32). Norwood, NJ: Ablex.

Delgado-Gaitan, C. (1990). Literacy for empowerment: The role of parents in children's education. New York: Falmer Press.

Delpit, L. D. (1988). The silenced dialogue: Power and pedagogy in educating other people's children. Harvard Educational Review, 58(3), 280-298.

Dianda, M. R., Madden, N. A., \& Slavin, R. E. (1993, April). Lee Conmigo: "Success for All" in schools serving limited English proficient students. Paper presented at annual meeting of the American Educational Research Association, Atlanta.

Elley, W. B., \& Mangubhai, F. (1983). The impact of reading on second language learning. Reading Research Quarterly, 19(1), 53-67.

Englert, C. S. (1993, April). A principled search for understanding: Strategic instruction. Paper presented at annual meeting of the American Educational Research Association, Atlanta.

Figueroa, R. A. (1989). Psychological testing of linguistic-minority students: Knowledge gaps and regulations. Exceptional Children, 56(2), 111-119.

Fradd, S. H. (1987). Accommodating the needs of limited English proficient students in regular classrooms. In S. Fradd \& W. Tikunoff (Eds.), Bilingual education and special education: A guide for administrators (pp. 133-182). Boston: Little, Brown.

Fradd, S. H., \& Weismantel, M. J. (1987, November). Education for the future: Meeting the needs of limited English proficient handicapped and at risk students through INFUSION and collaboration. Paper presented at National Conference on the Future of Special Education, Orlando, FL.

Garcia, E. (1993). Project THEME: Collaboration for school improvement at the middle school for language minority students. In Proceedings of the Third National Research Symposium on Limited English Proficient Student Issues: Focus on Middle and High School Issues (pp. 323-350). Washington, DC: U.S. Department of Education, Office of Bilingual Education and Minority Language Affairs. 
García, G. E. (1991). Factors influencing the English reading test performance of Spanish-speaking Hispanic children. Reading Research Quarterly, 26(4), 371-392.

Gartner, A., \& Lipsky, D. K. (1987). Beyond special education: Toward a quality system for all students. Harvard Educational Review, 57, 367-395.

Gersten, R. (1993, April). The language minority student in transition: Defining effective practices for literacy instruction. Paper presented at annual conference of American Educational Research Association, Atlanta.

Gersten, R., \& Jiménez, R. (1994). A delicate balance: Enhancing literacy instruction for students of English as a second language. Reading Teacher, 47(6).

Gersten, R., \& Morvant, M. (1994). Close to the bone: Emerging themes from a qualitative study of the process of classroom change. Manuscript submitted for publication.

Gersten, R., Taylor, R., \& Graves, A. (in press). Direct instruction and diversity. In L. Meyer \& C. Utley (Eds.), The school reform movement: Implementing effective schooling practices and intervention strategies for multicultural students with mild disabilities. Baltimore: Paul Brookes.

Gersten, R., \& Woodward, J. (1994a). The language minority student and special education: Issues, themes and paradoxes. Exceptional Children, 60(4), 310-322.

Gersten, R., \& Woodward, J. (1994b). Lost opportunities: Observations of the education of language minority students. Paper presented at annual meeting of the American Educational Research Association, New Orleans.

Gersten, R., \& Woodward, J. (in press). A longitudinal study of transitional and immersion bilingual education programs in one district. Elementary School Journal.

Goldenberg, C. (1987). Low-income Hispanic parents' contributions to their first-grade children's word recognition skills. Anthropology \& Education Quarterly, 18(2), 149-179.

Goldenberg, C. (1992/1993). Instructional conversations: Promoting comprehension through discussion. Reading Teacher, 46(4), 316-326.

Goldenberg, C., \& Gallimore, R. (1991). Local knowledge, research knowledge, and educational change: A case study of early Spanish reading improvement. Educational Researcher, 20(8), 2-14.

Gottlieb, J., Alter, J., \& Gottlieb, B. W. (1994). Special education in urban America: It's not justifiable for many. Journal of Special Education, 27(4), 453-465.

Greene, M. (1993). The passions of pluralism: Multiculturalism and the expanding community. Educational Researcher, 22(1), 13-18.

Hakuta, K. (1986). Mirror of language. New York: Basic Books.

Hakuta, K. (1990). Language and cognition in bilingual children. In A. M. Padilla, H. H. Fairchild, \& C. Valadez (Eds.), Bilingual education: Issues and strategies (pp. 47-59). Newbury Park, CA: Sage.

Hakuta, K., \& Snow, C. (1986). The role of research in policy decisions about bilingual education. NABE News, 9(3), 1, 18-21.

Harris, K., \& Pressley, M. (1991). The nature of cognitive strategy instruction: Interactive strategy construction. Exceptional Children, 57(5), 392-404.

Harry, B., Torguson, C., Katkavich, J., \& Guerrero, M. (1993). Crossing social class and cultural barriers in working with families: Implications for teacher training. Teaching Exceptional Children, 26(1), 48-51.

Jacobs, L. (1991). Assessment concerns: A study of cultural differ- ences, teacher concepts, and inappropriate labeling. Teacher Education \& Special Education, 14(1), 43-48.

Keating, T. (1993). An analysis of concerns identified by siblings and mothers during the transition to adulthood of family members with developmental disabilities. Unpublished doctoral dissertation, University of Oregon, Eugene.

Krashen, S. (1982). Principles and practice in second language acquisition. New York: Pergamon.

Lacelle-Peterson, M. W., \& Rivera, C. (1994). Is it real for all kids? A framework for equitable assessment policies for English language learners. Harvard Educational Review, 64(1), 55-75.

Long, M. H. (1983). Native speaker/non-native speaker conversation in the second language classroom. In M. A. Clarke \& J. Handscombe (Eds.), On TESOL 1982: Pacific perspectives on language learning and teaching (pp. 207-225). Washington, DC: TESOL.

McConnell, B. (1989). Education as a cultural process: The interaction between community and classroom in fostering learning. In J. B. Allen \& J. Mason (Eds.), Risk makers, risk takers, risk breakers: Reducing the risks for young children. Portsmouth, NH: Heinemann Educational Publications.

McElroy-Johnson, B. (1993). Giving voice to the voiceless. Harvard Educational Review, 63(1), 85-104.

McGroarty, M. (1989). The benefits of cooperative learning arrangements in second language instruction. NABE Journal, pp. $127-141$.

Mehan, H., Hertweck, A., \& Meihls, J. L. (1986). Handicapping the handicapped. Stanford, CA: Stanford University Press.

Mercer, J. R., \& Rueda, R. (1991, November). The impact of changing paradigms of disabilities on assessment for special education. Paper presented at Council for Exceptional Children topical conference on at-risk children and youth, New Orleans.

Moecker, D. L. (1992, November). Special education decision processes for Anglo and Hispanic students. Paper presented at Council for Exceptional Children topical conference on culturally and linguistically diverse exceptional children, Minneapolis.

Moll, L. C., \& Diaz, S. (1987). Change as the goal of educational research. Anthropology \& Education Quarterly, 18(4), 300 311.

National Advisory Council on Bilingual Education. (1987). Eighth annual report to Congress. Washington, DC: U.S. Government Printing Office.

National Center for Education Statistics. (1994). Language characteristics and schooling in the United States: A changing picture: 1979 and 1989. U.S. Department of Education, Office of Educational Research and Improvement.

Natriello, G., McDill, E. L., \& Pallas, A. M. (1990). Schooling disadvantaged children: Racing against catastrophe. New York: Teachers College Press.

Nieto, S. (1992). Affirming diversity: The sociopolitical context of multicultural education. White Plains, NY: Longman.

Ogbu, J. U. (1990). Minority status and literacy in comparative perspective. Daedalus, 119(2), 141-167.

Ortiz, A., \& Garcia, S. (1988). A prereferral process for preventing inappropriate referrals of Hispanic students to special education. In A. Ortiz \& B. Ramirez (Eds.), Schools and the culturally diverse exceptional students: Promising practices and future directions (pp. 6-18). Reston, VA: Council for Exceptional Children. 
OSEP Language Minority Researchers' Conference. (1992, October). A research agenda for language minority students in special education: A working paper. Eugene, OR: Eugene Research Institute.

Palincsar, A. S. (1993, April). Designing best contexts for learning. Paper presented at annual meeting of American Educational Research Association, Atlanta.

Prawat, R. S. (1992). Teachers' beliefs about teaching and learning: A constructivist perspective. American Journal of Education, $100(3), 354-395$.

Pugach, M. C., \& Warger, C. L. (1993). Curriculum considerations. In J. I. Goodlad \& T. C. Lovitt (Eds.), Integrating general and special education (pp. 125-148). New York: Macmillan.

Ramírez, J. D. (1992). Executive summary: Longitudinal study of structured English immersion strategy, early-exit and late-exit transitional bilingual education programs for languageminority children. Bilingual Research Journal, 16(1), 1-62.

Reyes, M. (1992). Challenging verable assumptions: Literacy instruction for linguistically different students. Harvard Educational Review, 62(4), 427-446.

Rueda, R. (1994, April). The impact of traditional versus portfolio-based assessment on educators' evaluation of literacy with language minority students. Paper presented at annual meeting of American Educational Research Association, New Orleans.

Ruiz, N. T. (1989). An optimal learning environment for Rosemary. Exceptional Children, 56(2), 130-144.

Schiff-Myers, N. B., Djukic, J., Lawler-McGovern, J., \& Perez, D. (1994). Assessment considerations in the evaluation of second-language learners: A case study. Exceptional Children, 60(3), 237-248.

Shapiro, J. P., Loeb, P., \& Bowermaster, D. (1992, December 13). Separate and unequal: How special education programs are cheating our children and costing taxpayers billions each year. U.S. News and World Report, pp. 46-56.

Singer, J. D., \& Butler, J. A. (1987). The Education for All Handicapped Children Act: Schools as agents of social reform. Harvard Educational Review, 57(2), 125-152.

Stainback, W., \& Stainback, S. (1991). Rationale for integration and restructuring: A synopsis. In J. W. Lloyd, A. C. Repp, \& N. N. Singh (Eds.), The regular education initiative: Alternative perspectives on concepts, issues and models (pp. 225239). Sycamore, IL: Sycamore.
Suro, R. (1990, November 4). Hispanics in despair. New York Times.

Teale, W. H. (1986). Home background and young children's literacy development. In W. H. Teale \& E. Sulzby (Eds.), Emergent literacy: Writing and reading (pp. 173-206). Norwood, NJ: Ablex.

Tharp, R. G., \& Gallimore, R. (1988). Rousing minds to life. Cambridge, UK: Cambridge University Press.

Tikunoff, W. J. (1985). Applying significant bilingual instructional features in the classroom. Rosslyn, VA: National Clearinghouse for Bilingual Education.

U.S. Department of Commerce. (1990). U.S. Census. Washington, DC: Bureau of the Census.

Waggoner, D. (1991). Undereducation in America: The demography of high school dropouts. New York: Auburn House.

Wilkinson, C., \& Ortiz, A. (1986). Characteristics of limited English proficient and English proficient learning disabled Hispanic students at initial assessment and at reevaluation. Austin: University of Texas, Department of Special Education, Handicapped Minority Research Institute.

Wong-Fillmore, L., \& Valdez, C. (1986). Teaching bilingual learners. In M. C. Wittrock (Ed.), Handbook of research on teaching (pp. 648-685). New York: Macmillan.

Yates, J. R. (1993). President's message. Council for Exceptional Children Division for Culturally and Linguistically Diverse Exceptional Learners News, 4(1), 1, 3.

Yates, J. R., \& Ortiz, A. A. (1991). Professional development needs of teachers who serve exceptional language minorities in today's schools. Teacher Education \& Special Education, 14(1), 11-18.

Ysseldyke, J., O’Sullivan, P. J., Thurlow, M., \& Christenson, S. (1989). Qualitative differences in reading and math instruction received by handicapped students. Remedial \& Special Education, 10(1), 14-20.

This research was supported in part by Grant No. HO23H00014 from the Division of Innovation and Development, Office of Special Education Programs, U.S. Department of Education. The authors wish to thank Thomas Keating for his organizational wizardry, Matt Cranor and Damion Jurrens for their extensive assistance in the preparation of this manuscript, and David Chard for extremely valuable feedback on an earlier version.

PERMISSIONS AND COPYRIGHT• All rights are reserved. No part of this publication may be reproduced, photocopied, faxed, stored in a retrieval system, or transmitted, in any form or by any means, electronic, mechanical, recording or otherwise, without the prior written permission of the publisher. Back issues are available for sale. Reproduction requires permission and payment of fees. It is illegal and a violation of federal copyright law to reproduce this publication without permission. Direct all inquiries to the permissions editor. 